\title{
Thermovibrio ammonificans sp. nov., a thermophilic, chemolithotrophic, nitrate-ammonifying bacterium from deep-sea hydrothermal vents
}

\author{
Correspondence \\ Costantino Vetriani \\ vetriani@imcs.rutgers.edu
}

\author{
Costantino Vetriani, ${ }^{1,2}$ Mark D. Speck, ${ }^{2}$ Susan V. Ellor, ${ }^{2}$ Richard A. Lutz ${ }^{2}$ \\ and Valentin Starovoytov ${ }^{3}$
}

\author{
${ }^{1}$ Department of Biochemistry and Microbiology, Rutgers University, New Brunswick, NJ 08901, \\ USA \\ 2Institute of Marine and Coastal Sciences, Rutgers University, New Brunswick, NJ 08901, USA \\ ${ }^{3}$ Department of Cell Biology and Neuroscience, Rutgers University, Piscataway, NJ 08854, \\ USA
}

\begin{abstract}
A thermophilic, anaerobic, chemolithoautotrophic bacterium was isolated from the walls of an active deep-sea hydrothermal vent chimney on the East Pacific Rise at $9^{\circ} 50^{\prime} \mathrm{N}$. Cells of the organism were Gram-negative, motile rods that were about $1.0 \mu \mathrm{m}$ in length and $0.6 \mu \mathrm{m}$ in width. Growth occurred between 60 and $80^{\circ} \mathrm{C}$ (optimum at $75^{\circ} \mathrm{C}$ ), 0.5 and $4.5 \%(\mathrm{w} / \mathrm{v}) \mathrm{NaCl}$ (optimum at $2 \%$ ) and $\mathrm{pH} 5$ and 7 (optimum at 5.5). Generation time under optimal conditions was 1.57 h. Growth occurred under chemolithoautotrophic conditions in the presence of $\mathrm{H}_{2}$ and $\mathrm{CO}_{2}$, with nitrate or sulfur as the electron acceptor and with concomitant formation of ammonium or hydrogen sulfide, respectively. Thiosulfate, sulfite and oxygen were not used as electron acceptors. Acetate, formate, lactate and yeast extract inhibited growth. No chemoorganoheterotrophic growth was observed on peptone, tryptone or Casamino acids. The genomic DNA G +C content was 54.6 mol\%. Phylogenetic analyses of the $16 \mathrm{~S}$ rRNA gene sequence indicated that the organism was a member of the domain Bacteria and formed a deep branch within the phylum Aquificae, with Thermovibrio ruber as its closest relative ( $94.4 \%$ sequence similarity). On the basis of phylogenetic, physiological and genetic considerations, it is proposed that the organism represents a novel species within the newly described genus Thermovibrio. The type strain is Thermovibrio ammonificans $\mathrm{HB}-1^{\top}$ $\left(=\right.$ DSM $15698^{\top}=$ JCM $\left.12110^{\top}\right)$.
\end{abstract}

Bacterial growth by respiratory nitrate reduction results in the production of either dinitrogen (respiratory denitrification) or ammonium (respiratory nitrate ammonification). Recently, several organisms that obtain energy from the reduction of nitrate to ammonium at elevated temperatures were isolated from geothermal environments. Among these organisms, most of which represent novel genera that are spread over a wide range of phylogenetic groups, Ammonifex degensii is a thermophilic bacterium that was isolated from a continental hot spring and is related to the low- $\mathrm{G}+\mathrm{C}$ subgroup of Gram-positive bacteria

Published online ahead of print on 18 July 2003 as DOI 10.1099/ ijs.0.02781-0.

The GenBank/EMBL/DDBJ accession number for the 16S rRNA gene sequence of strain $\mathrm{HB}-1^{\top}$ is $\mathrm{AY} 263403$.

Graphs showing the growth of strain $\mathrm{HB}-1^{\top}$ under different conditions are available as supplementary material in IJSEM Online.
(Huber et al., 1996). Caminibacter hydrogeniphilus is a thermophilic $\varepsilon$-proteobacterium that was isolated from a deep-sea hydrothermal vent (Alain et al., 2002). 'Desulfurobacterium crinifex' and Thermovibrio ruber are thermophilic bacteria that were isolated recently from a deep-sea and a shallow-water hydrothermal vent, respectively (Huber et al., 2002; Alain et al., 2003). T. ruber, together with its closest relatives, 'D. crinifex' and Desulfurobacterium thermolithotrophum, may represent a novel order within the phylum Aquificae (L'Haridon et al., 1998; Huber et al., 2002). Ammonifex degensii, C. hydrogeniphilus, 'D. crinifex' and $T$. ruber are able to use elemental sulfur (in addition to nitrate) as an alternative electron acceptor, with concomitant production of hydrogen sulfide. Pyrolobus fumarii is a hyperthermophilic archaeon (kingdom Crenarchaeota) that was isolated from a deep-sea hydrothermal vent; it can grow by nitrate ammonification, thiosulfate reduction and microaerophilic hydrogen oxidation (Blöchl et al., 1997). 
Caldithrix abyssi was isolated recently from a deep-sea hydrothermal vent and represents a novel bacterial lineage, the phylogenetic position of which remains uncertain (Miroshnichenko et al., 2003). In contrast to Ammonifex degensii, 'D. crinifex', T. ruber and P. fumarii, which are all chemolithoautotrophs, C. abyssi can grow either chemoorganoheterotrophically by fermentation of proteinaceous substrates, or chemolithoheterotrophically by reduction of nitrate to ammonium, using yeast extract as a carbon source. Here, we describe the isolation and characterization of a novel thermophilic, chemolithoautotrophic, strictly anaerobic, nitrate-ammonifying bacterium that was isolated from a deep-sea hydrothermal vent on the East Pacific Rise.

Fragments of several active black smoker chimneys were collected from the East Pacific Rise $\left(9^{\circ} 50^{\prime} \mathrm{N}, 104^{\circ} 18^{\prime} \mathrm{W}\right)$ at a depth of $2500 \mathrm{~m}$, during two cruises aboard RV Atlantis (November 1999 and April 2000). Samples were collected by using the manipulator of the deep-submergence vehicle Alvin and stored in boxes on the submersible's working platform for the rest of the dive. On the surface, samples were transferred promptly to the ship's laboratory and subsamples were placed in stoppered tubes, reduced with a $5 \%$ solution of $\mathrm{Na}_{2} \mathrm{~S}$ and stored at $4{ }^{\circ} \mathrm{C}$. Portions of the subsamples were used immediately for shipboard inocula by injecting $1 \mathrm{ml}$ slurry (obtained by resuspension of about $1 \mathrm{~g}$ chimney rock in $1 \mathrm{ml}$ anaerobic, sterile, artificial sea water) into $10 \mathrm{ml}$ culture medium.

Isolate $\mathrm{HB}-1^{\mathrm{T}}$ was grown routinely in modified SME medium (Stetter et al., 1983), which contained $\left(1^{-1}\right)$ : $\mathrm{NaCl}, 20.0 \mathrm{~g} ; \mathrm{MgSO}_{4} .7 \mathrm{H}_{2} \mathrm{O}, 3.5 \mathrm{~g} ; \mathrm{MgCl}_{2} \cdot 6 \mathrm{H}_{2} \mathrm{O}, 2.75 \mathrm{~g}$; $\mathrm{KCl}, 0.325 \mathrm{~g} ; \mathrm{KNO}_{3}, 1.0 \mathrm{~g} ; \mathrm{NaBr}, 50.0 \mathrm{mg} ; \mathrm{H}_{3} \mathrm{BO}_{3}$, $15.0 \mathrm{mg} ; \mathrm{SrCl}_{2} .6 \mathrm{H}_{2} \mathrm{O}, 7 \cdot 5 \mathrm{mg} ;\left(\mathrm{NH}_{4}\right)_{2} \mathrm{SO}_{4}, 10.0 \mathrm{mg} ; \mathrm{KI}$, $0.05 \mathrm{mg} ; \mathrm{Na}_{2} \mathrm{WO}_{2} .2 \mathrm{H}_{2} \mathrm{O}, 0.1 \mathrm{mg} ; \mathrm{CaCl}_{2} .2 \mathrm{H}_{2} \mathrm{O}, 0.75 \mathrm{~g}$; $\mathrm{KH}_{2} \mathrm{PO}_{4}, 0.5 \mathrm{~g} ; \mathrm{NiCl}_{2} .6 \mathrm{H}_{2} \mathrm{O}, 2.0 \mathrm{mg}$; resazurin, $1.0 \mathrm{mg}$; trace element solution, $10 \mathrm{ml}$ (Balch et al., 1979). After solubilization, the medium was heated to boiling point and then cooled under a stream of $\mathrm{N}_{2}$ for $30 \mathrm{~min}$. $\mathrm{Na}_{2} \mathrm{~S} .9 \mathrm{H}_{2} \mathrm{O}\left(0.5 \mathrm{~g} \mathrm{l}^{-1}\right)$ was added to reduce the medium and the $\mathrm{pH}$ was adjusted to $5 \cdot 5$ with $\mathrm{H}_{2} \mathrm{SO}_{4}$. The medium was then aliquoted ( $10 \mathrm{ml}$ portions) into tightly stoppered tubes (Bellco Glass) and autoclaved $(200 \mathrm{kPa}, 20 \mathrm{~min}$, $121^{\circ} \mathrm{C}$ ). Prior to inoculation, the medium was supplemented aseptically with $0 \cdot 25 \mathrm{ml}$ MES buffer $(20 \%$, w/v; pH 5.5), $0 \cdot 1 \mathrm{ml} \mathrm{KNO} 3\left(10 \%\right.$, w/v) and $0.04 \mathrm{ml} \mathrm{Na}_{2} \mathrm{~S}_{2} 9 \mathrm{H}_{2} \mathrm{O}$ ( $3 \%$, w/v; $\mathrm{pH} 7 \cdot 0)$; it was pressurized with $\mathrm{H}_{2} / \mathrm{CO}_{2}$ (80:20; $200 \mathrm{kPa}$ ). Cultures were incubated at $75^{\circ} \mathrm{C}$. Stocks of strain HB- $1^{\mathrm{T}}$ for long-term storage were prepared by supplementing $1 \mathrm{ml}$ culture with $50 \mu \mathrm{l}$ DMSO (Fisher Scientific) and were stored at $-80^{\circ} \mathrm{C}$. Growth of strain $\mathrm{HB}-1^{\mathrm{T}}$ was determined by direct counts of acridine orange-stained cells by epifluorescence microscopy, using an ocular grid. All growth experiments were carried out in duplicate. Growth rates $\left(\mu ; \mathrm{h}^{-1}\right)$ were estimated as: $\mu=\left(\ln \mathrm{N}_{2}-\ln \mathrm{N}_{1}\right) /\left(t_{2}-t_{1}\right)$, where $N_{2}$ and $N_{1}$ are no. cells $\mathrm{ml}^{-1}$ at time (in h) $t_{2}-t_{1}$. Generation times $\left(t_{\mathrm{g}} ; \mathrm{h}\right)$ were calculated as: $t_{\mathrm{g}}=(\ln 2) / \mu$.
To determine the optimal growth temperature for strain $\mathrm{HB}-1^{\mathrm{T}}$, cultures were incubated between 50 and $85^{\circ} \mathrm{C}$ (at $5^{\circ} \mathrm{C}$ intervals). All other experiments were carried out at $75^{\circ} \mathrm{C}$. To determine optimal salt requirement, the concentration of $\mathrm{NaCl}$ was varied between 0 and $5 \%(\mathrm{w} / \mathrm{v})$. The influence of $\mathrm{pH}$ on growth was determined between $\mathrm{pH} 4.0$ and 8.5 by using the following buffers at a concentration of $10 \mathrm{mM}$ : acetate at $\mathrm{pH} 4 \cdot 0,4 \cdot 5$ and $5 \cdot 0$; MES at $\mathrm{pH} 5 \cdot 5$ and $6 \cdot 0$; PIPES at $\mathrm{pH} 6 \cdot 5,7 \cdot 0$ and $7 \cdot 5$; and Tris at $\mathrm{pH} 8 \cdot 0$ and $8 \cdot 5$. Susceptibility of strain HB- $1^{\mathrm{T}}$ to antibiotics was tested in the presence of ampicillin, chloramphenicol, kanamycin and streptomycin (each at $100 \mu \mathrm{g} \mathrm{ml}^{-1}$ ). All antibiotics were added aseptically to the culture medium before incubation at $75^{\circ} \mathrm{C}$. To investigate the effect of organic substrates on the growth of strain HB$1^{\mathrm{T}}$, acetate, formate, lactate, peptone, tryptone, Casamino acids, $\mathrm{D}-(+)$-glucose and sucrose (each at $2 \mathrm{~g} \mathrm{l}^{-1}$ ) and yeast extract (at $0 \cdot 1$ and $1 \mathrm{~g} \mathrm{l}^{-1}$ ) were added to the medium under an $\mathrm{H}_{2} / \mathrm{CO}_{2}$ gas phase $(80: 20 ; 200 \mathrm{kPa})$. The same compounds at the same concentrations were also tested as possible energy and/or carbon sources by using $\mathrm{N}_{2} / \mathrm{CO}_{2}$ $(80: 20 ; 200 \mathrm{kPa}), \mathrm{N}_{2}(100 \% ; 200 \mathrm{kPa})$ or $\mathrm{H}_{2}(100 \%$; $200 \mathrm{kPa}$ ) as the gas phase. In order to determine the ability of strain $\mathrm{HB}-1^{\mathrm{T}}$ to use alternative electron acceptors, thiosulfate $(0 \cdot 1 \%, \mathrm{w} / \mathrm{v})$, sulfite $(0 \cdot 1 \%, \mathrm{w} / \mathrm{v})$, sulfur $(3 \%, \mathrm{w} / \mathrm{v})$ and oxygen $(0.5 \%)$ were used to supplement nitratedepleted medium. Cells were stained routinely with $0 \cdot 1 \%$ acridine orange and visualized with an Olympus BX 60 microscope with an oil-immersion UPlanF1 $100 \times / 1.3$ objective lens. For ultrathin sections, cells were fixed for $3 \mathrm{~h}$ in Karnovsky's fixative (formaldehyde, $4 \% \mathrm{v} / \mathrm{v}$ and glutaraldehyde, $1 \% \mathrm{v} / \mathrm{v}$, in $0 \cdot 1 \mathrm{M}$ Millonig's phosphate buffer, $\mathrm{pH} 7 \cdot 3$ ), followed by incubation in $1 \%$ osmium tetroxide for $1 \mathrm{~h}$ and dehydration in a graded ethanol series. Cells were then embedded in Epon-Araldite and sectioned with a diamond knife by using an LKB 2088 ultramicrotome (LKBProdukter). Thin sections were stained with $5 \%$ uranyl acetate (w/v) solution in $50 \%$ ethanol for $15 \mathrm{~min}$ and then with $0.5 \%$ lead citrate $(\mathrm{w} / \mathrm{v})$ solution in $\mathrm{CO}_{2}$-free, doubledistilled water for $2 \mathrm{~min}$. For direct visualization, cells were fixed and applied onto a copper Formvar/carbon-coated grid. The grids were air-dried and shadowed with $2 \mathrm{~nm} \mathrm{Pt} / \mathrm{C}$ (angle, $15^{\circ}$ ) by using a High Vacuum Freeze-Etch unit BAF 300 (Balzers). Electron micrographs were taken on a model JEM 100 CX transmission electron microscope (JEOL).

Quantitative nitrate, nitrite and $\mathrm{NH}_{3}$ determinations were carried out spectrometrically by using a Lachat QuikChem automated ion analyser according to the manufacturer's specifications (Diamond, 1993). Qualitative hydrogen sulfide determination was carried out according to CordRuwisch (1985). For the determination of catalase activity, cells were collected by centrifugation from duplicate $15 \mathrm{ml}$ overnight cultures, resuspended in $70 \mu \mathrm{l} 3 \% \mathrm{H}_{2} \mathrm{O}_{2}$ solution and incubated at both $75^{\circ} \mathrm{C}$ and room temperature. A cell-free $3 \% \mathrm{H}_{2} \mathrm{O}_{2}$ solution was used as a negative control. The presence of catalase was detected by the formation of gas bubbles. 
DNA was isolated from T. ruber and HB- ${ }^{\mathrm{T}}$ cells (about $2.5 \mathrm{~g}$ wet wt) by using a French pressure cell (Thermo Spectronic) and was purified by chromatography on hydroxyapatite, as described by Cashion et al. (1977). DNA-DNA hybridization was carried out as described by De Ley et al. (1970) with the modifications described by Huss et al. (1983) and Escara \& Hutton (1980), using a model 2600 spectrophotometer equipped with a model 2527-R thermoprogrammer and plotter (Gilford Instrument Laboratories). Renaturation rates were computed with the TRANSFER.BAS program of Jahnke (1992). The determination of DNA base composition was carried out according to Mesbah et al. (1989). The 16S rRNA gene was amplified selectively from genomic DNA by PCR, as described previously (Vetriani et al., 1999), using primers 27F (5'-AGAGTTTGATCCTGGCTCAG-3') (Giovannoni, 1991) and 1517R (5'-ACGGCTACCTTGTTACGACTT-3') (Weisburg et al., 1991). The amplified 16S rRNA gene was cloned in pCR II plasmid vector (Invitrogen) and the resulting ligation product was used to transform competent Escherichia coli Top10F' cells. A recombinant clone was selected and the sequence of the 16S rRNA gene was determined for both strands on an ABI 310 automated sequencer (Applied Biosystems). Phylogenetic analyses were carried out as described previously (Vetriani et al., 1999).

Enrichment cultures for thermophilic, chemolithotrophic organisms were obtained by inoculating $10 \mathrm{ml}$ anaerobic SME medium (Stetter et al., 1983), supplemented with $0 \cdot 1 \%$ nitrate, with approximately $1 \mathrm{ml}$ slurry obtained from high-temperature active vents located on the East Pacific Rise at $9^{\circ} 50^{\prime} \mathrm{N}$. Hydrothermal fluid temperatures at the time of sampling were $327-353^{\circ} \mathrm{C}$. Several enrichment cultures were initiated aboard ship and were incubated at $80{ }^{\circ} \mathrm{C}$ without shaking, with $\mathrm{H}_{2} / \mathrm{CO}_{2}$ as the gas phase $(80: 20 ; 200 \mathrm{kPa})$. Within $1-2$ days incubation, turbidity caused by cell growth was observed and $0 \cdot 1 \mathrm{ml}$ was transferred successfully to fresh medium. Upon return to the laboratory, seven independent enrichment cultures, which originated from four different active chimneys (Ty, Q, Bio9' and Tubeworm Pillar vents), showed consistent growth after repeated transfers to fresh medium. All cultures contained short rods that were similar in morphology but slightly different in size and were designated as strains HB- $1^{\mathrm{T}}-\mathrm{HB}-7$. Preliminary $16 \mathrm{~S}$ rRNA gene sequence analysis showed that all strains were closely related. One enrichment culture was selected and the organism was purified by four series of end-point dilutions. The resulting isolate was designated strain $\mathrm{HB}-\mathrm{1}^{\mathrm{T}}$.

Cells of HB- ${ }^{\mathrm{T}}$ were short rods, about $1.0 \mu \mathrm{m}$ in length and $0.6 \mu \mathrm{m}$ in width (Fig. 1a-c). Cells stained Gramnegative. Most ultrathin sections revealed large lowelectron-density areas within the cytoplasm that did not

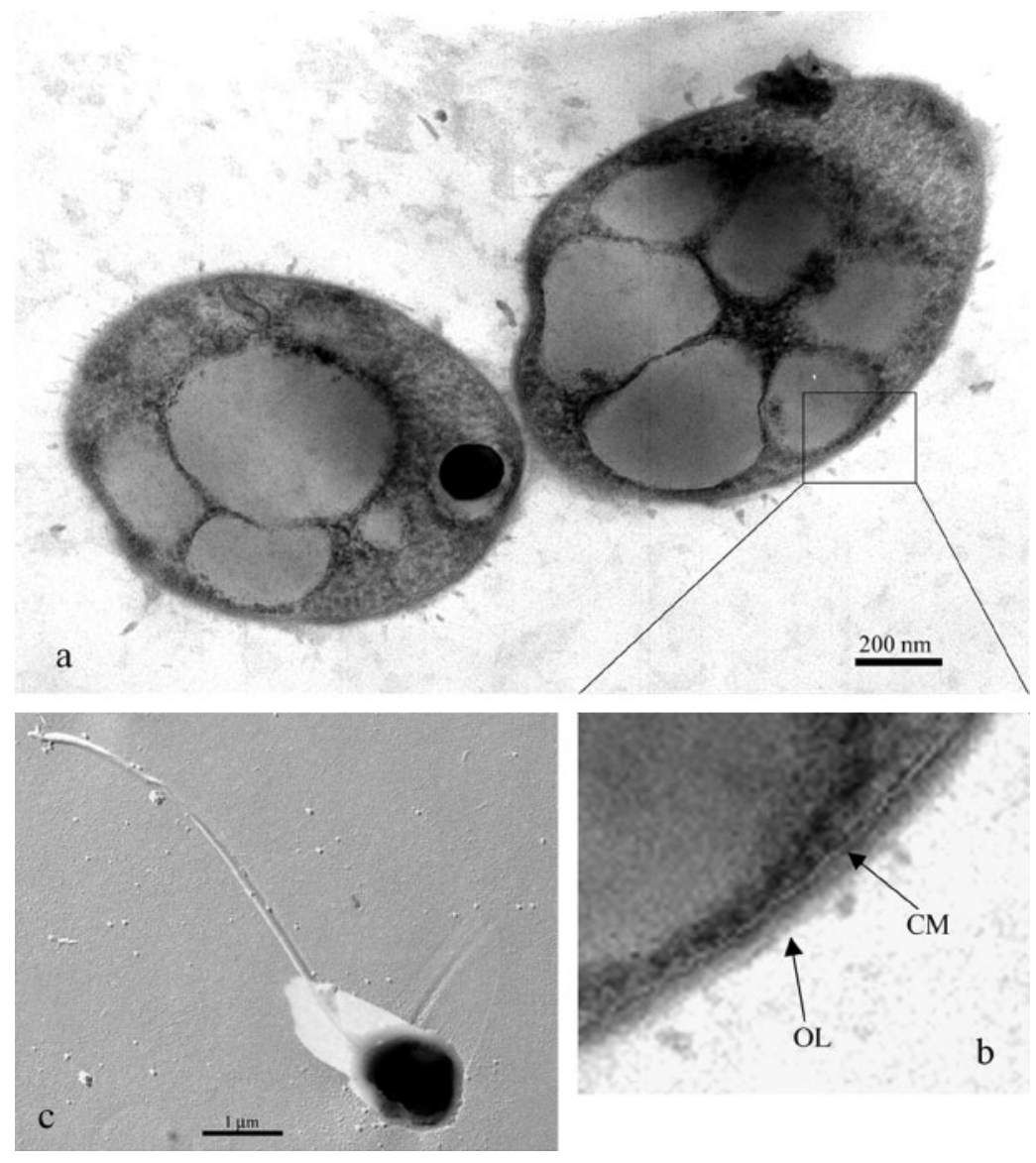

Fig. 1. (a) Electron micrograph of a thin section of cells of strain $\mathrm{HB}-1^{\top}$, showing morphology and the presence of low-electrondensity areas within the cytoplasm. (b) Ultrastructural details of the cell envelope of strain $\mathrm{HB}-1^{\top}$; $\mathrm{CM}$, cytoplasmic membrane; $\mathrm{OL}$, outside layer. (c) Electron micrograph of a platinum-shadowed cell of strain $\mathrm{HB}-1^{\top}$, showing a polar flagellum. 
appear to be delimited by a membrane (Fig. 1a). These areas may therefore be inclusions that contain energystorage polymers. Cytoplasmic protrusions were often observed in ultrathin sections (Fig. 1a). The cell envelope of strain HB- $1^{\mathrm{T}}$ included a cytoplasmic membrane that was surrounded by a $20 \mathrm{~nm}$ thick, low-electron-density layer (Fig. 1b). The organism was motile and possessed one to two terminal flagella, which were observed in electron micrographs of platinum-shadowed cells (Fig. 1c). Cells divided by septum formation and the presence of endospores was not observed. Cell pellets exhibited a bright orange colour.

Strain HB- $1^{\mathrm{T}}$ grew at temperatures between 60 and $80{ }^{\circ} \mathrm{C}$, with an optimum growth temperature of $75^{\circ} \mathrm{C}$ and a generation time of $1.57 \mathrm{~h}$. No growth was detected at 55 or $85^{\circ} \mathrm{C} . \mathrm{HB}-1^{\mathrm{T}}$ grew at $\mathrm{NaCl}$ concentrations between $0 \cdot 5$ and $4.5 \%(\mathrm{w} / \mathrm{v})$, with optimum at $2 \%(\mathrm{w} / \mathrm{v}) \mathrm{NaCl}$ in the culture medium, corresponding to $0 \cdot 65 \times$ SME medium. Growth of strain HB- $1^{\mathrm{T}}$ occurred between $\mathrm{pH} 5$ and 7 , with optimum at around $\mathrm{pH} 5 \cdot 5$. No growth was detected at $\mathrm{pH}<5$ or $>7$. Strain $\mathrm{HB}-1^{\mathrm{T}}$ was a strictly anaerobic, chemolithotrophic organism that used nitrate as an electron acceptor and $\mathrm{H}_{2}$ as an electron donor. Under these conditions, strain $\mathrm{HB}-1^{\mathrm{T}}$ reduced nitrate to ammonium, which was produced in stoichiometric amounts as its main metabolic product (Fig. 2). Nitrite was not detected in the culture medium. When nitrate was replaced by sulfur in the culture medium, strain $\mathrm{HB}-1^{\mathrm{T}}$ was capable of growth and $\mathrm{H}_{2} \mathrm{~S}$ was detected as the final metabolic product (data not shown). However, when freshly grown cells of strain HB-1 ${ }^{\mathrm{T}}$ were transferred from nitrate- to sulfur-containing medium, they underwent a $12 \mathrm{~h}$ lag phase and the final number of cells was about three- to fourfold lower than that of cells grown with nitrate as the electron acceptor, even after repeated transfers in sulfur-containing media. Thiosulfate, sulfite and oxygen $(0.5 \% \mathrm{v} / \mathrm{v})$ were not used as electron acceptors when strain $\mathrm{HB}-1^{\mathrm{T}}$ was incubated in the presence of molecular hydrogen as an electron donor. Growth of HB- $1^{\mathrm{T}}$ was inhibited by the presence of oxygen $(0 \cdot 5 \%)$ in nitrate-containing media. In contrast, Aquifex pyrophilus showed robust growth under similar culture conditions with $\mathrm{H}_{2} / \mathrm{CO}_{2} / \mathrm{O}_{2}(79 \cdot 75: 19 \cdot 75: 0 \cdot 5 ; 200 \mathrm{kPa})$ as the gas phase.

No growth was observed when nitrate was used as an electron acceptor and strain $\mathrm{HB}-1^{\mathrm{T}}$ was incubated in the presence of acetate, formate, lactate or yeast extract $\left(1 \mathrm{~g} \mathrm{l}^{-1}\right)$ under an $\mathrm{H}_{2} / \mathrm{CO}_{2}$ headspace. Peptone, tryptone, Casamino acids, yeast extract $\left(0 \cdot 1 \mathrm{~g} \mathrm{l}^{-1}\right), \mathrm{D}-(+)$-glucose and sucrose did not affect growth under an $\mathrm{H}_{2} / \mathrm{CO}_{2}$ headspace, but no growth was observed in the presence of the same organic substrates under a $\mathrm{N}_{2} / \mathrm{CO}_{2}, \mathrm{~N}_{2}$ or $\mathrm{H}_{2}$ headspace. Growth of strain $\mathrm{HB}-1^{\mathrm{T}}$ was inhibited by ampicillin and chloramphenicol, but not by the aminoglycoside antibiotics kanamycin or streptomycin. Strain HB-1 ${ }^{\mathrm{T}}$ exhibited moderate gas production after concentrated cells were incubated in the presence of $\mathrm{H}_{2} \mathrm{O}_{2}$, both at $75^{\circ} \mathrm{C}$ and at room temperature. Cells of Aquifex pyrophilus, which were used as a

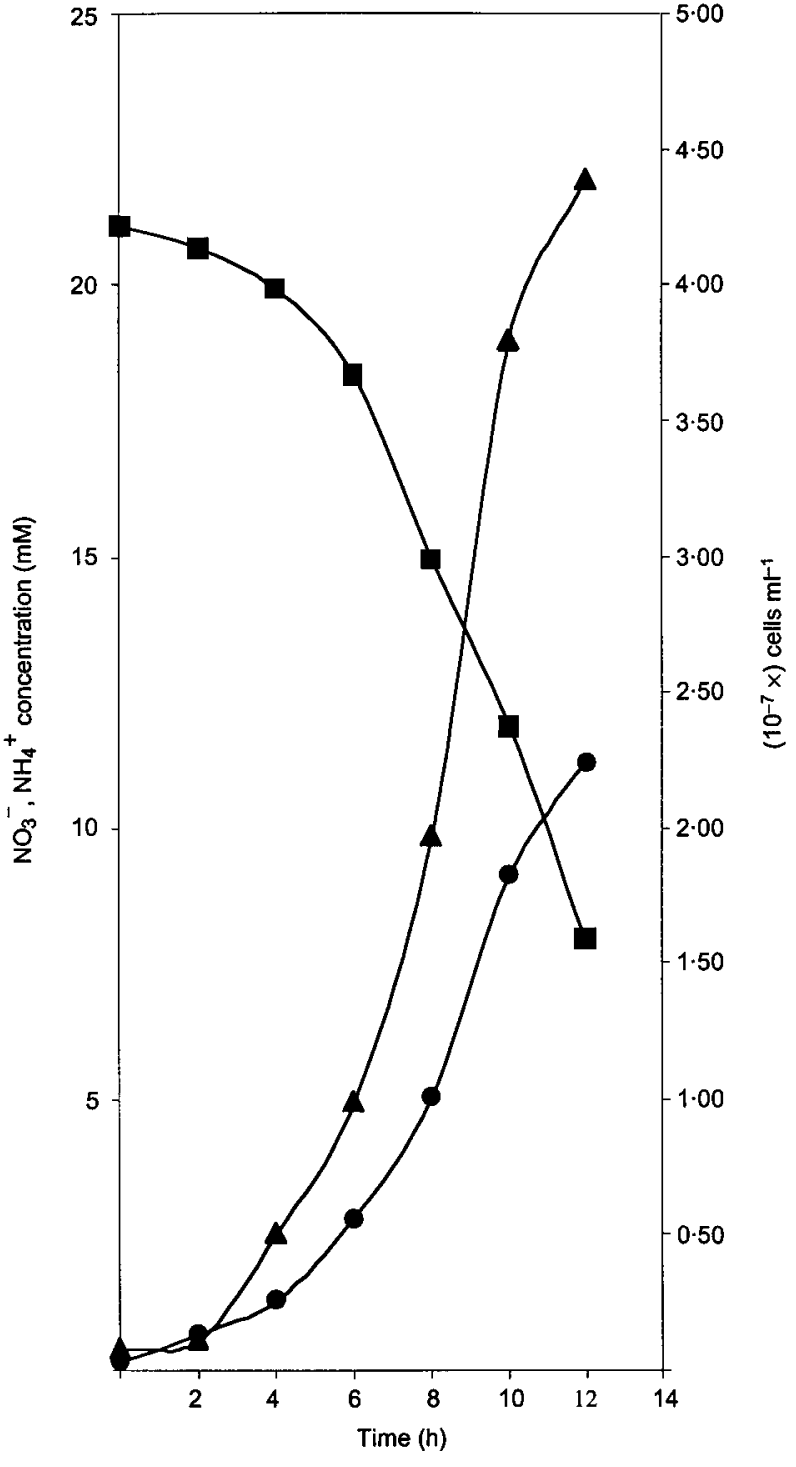

Fig. 2. Growth curve ( $\mathbf{\Delta})$, nitrate consumption ( $\boldsymbol{\square})$ and ammonium formation $(\bullet)$ during growth of strain $\mathrm{HB}-1^{\top}$.

positive control, exhibited gas production after being subjected to identical treatment. Whilst no attempt was made to quantify catalase activity, cells of Aquifex pyrophilus produced gas more vigorously than cells of $\mathrm{HB}-1^{\mathrm{T}}$.

The genomic DNA G+C content of strain $\mathrm{HB}-1^{\mathrm{T}}$, determined by HPLC analysis of deoxyribonucleosides, was $54.6 \mathrm{~mol} \%$. DNA-DNA hybridization experiments showed relatively low similarity between strain $\mathrm{HB}-1^{\mathrm{T}}$ and T. ruber $(55 \cdot 5 \%)$. Phylogenetic analyses of the $16 \mathrm{~S}$ rRNA gene sequence of strain $\mathrm{HB}-1^{\mathrm{T}}$, along with those of two closely related strains (designated as HB-2 and HB-4), were performed by using both evolutionary distance and maximum-likelihood methods for tree reconstruction. Both approaches were consistent in placing strain $\mathrm{HB}-1^{\mathrm{T}}$, as well as strains HB-2 and HB-4, within a deep branch of 


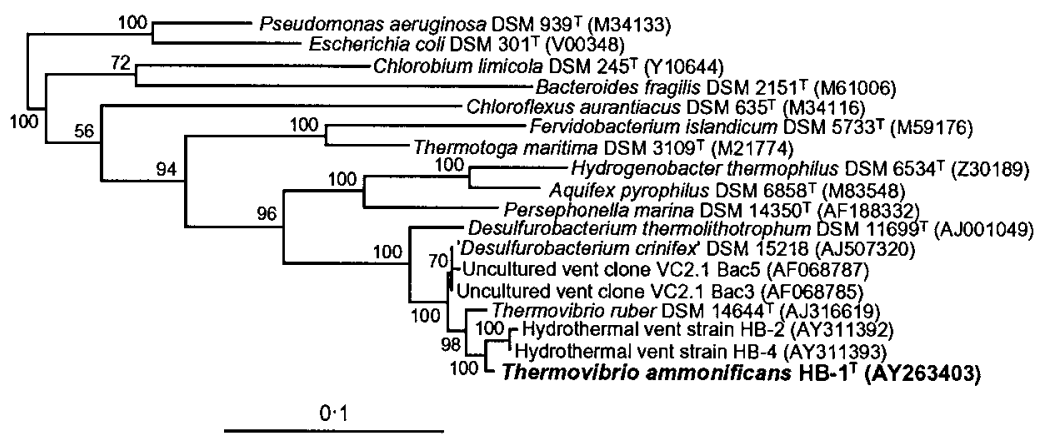

Fig. 3. Phylogenetic position of $T$. ammonificans (strain $\mathrm{HB}-1^{\top}$ ). The maximum-likelihood tree was constructed by using fastDNAml (Felsenstein, 1981). Bar, 10\% estimated base substitutions.

the bacterial phylum Aquificae (Fig. 3). In all analyses, the closest relative of strain $\mathrm{HB}-1^{\mathrm{T}}$ was $T$. ruber (Huber et al., 2002 ), the $16 \mathrm{~S}$ rRNA gene sequence of which was $94 \cdot 4 \%$ similar to that of $\mathrm{HB}-1^{\mathrm{T}}$. Furthermore, strain $\mathrm{HB}-1^{\mathrm{T}}$ was closely related (about $94 \%$ sequence similarity) to both 'D. crinifex' and D. thermolithotrophum (L'Haridon et al., 1998; Alain et al., 2003). Both methods of phylogenetic inference placed strain $\mathrm{HB}-1^{\mathrm{T}}$ in a distinct cluster with its close relatives $\mathrm{HB}-2$ and $\mathrm{HB}-4$ ( $>98 \%$ sequence similarity). However, the two methods provided two slightly different scenarios in terms of the phylogenetic position of T. ruber relative to that of strain $\mathrm{HB}-1^{\mathrm{T}}$. Whilst trees reconstructed by using the distance method placed $T$. ruber consistently with the ' $D$. crinifex' cluster (data not shown), maximumlikelihood analysis, supported by high bootstrap values, placed this organism closer to the HB cluster (Fig. 3). Detailed analysis of the secondary structure of the 16S rRNA gene of strain $\mathrm{HB}-1^{\mathrm{T}}$ revealed that the helix found at positions 198-219 (E. coli numbering) shares a structural feature that is common to most members of the order Aquificales (Burggraf et al., 1992; Reysenbach et al., 1994).

Based primarily on metabolic and phylogenetic considerations, strain $\mathrm{HB}-\mathrm{1}^{\mathrm{T}}$ can be assigned to the newly designated genus Thermovibrio (Huber et al., 2002). However, strain HB- ${ }^{\mathrm{T}}$ can be differentiated from $T$. ruber on the basis of its morphology (straight rod versus vibrioid), size, growth inhibition under certain culture conditions, $\mathrm{pH}$ and $\mathrm{NaCl}$ concentration for optimal growth and its DNA $G+C$ content (Table 1). In particular, the genomic DNA G $+\mathrm{C}$ content of strain $\mathrm{HB}-1^{\mathrm{T}}(54.6 \mathrm{~mol} \%)$ is higher than those of T. ruber (46 mol\%), D. thermolithotrophum (35 mol\%) and other representatives of the Aquificales (the $\mathrm{G}+\mathrm{C}$ content of which varies between 35 and $47 \cdot 5 \mathrm{~mol} \%$ ). Furthermore, as the DNA-DNA similarity of strain $\mathrm{HB}-1^{\mathrm{T}}$ and T. ruber is only $55.5 \%$, the two organisms are not related at the species level (Wayne et al., 1987). Therefore, strain $\mathrm{HB}-\mathrm{I}^{\mathrm{T}}$ represents a novel species within the genus Thermovibrio, for which we propose the name Thermovibrio ammonificans (type strain, $\mathrm{HB}-1^{\mathrm{T}}$ ).

The mineralogy of deep-sea hydrothermal vent chimneys is determined mainly by the temperature, chemical composition and flux rate of the end-member fluid (Tivey, 1995). The mineral composition of the chimneys determines their porosity, which in turn affects the steep thermal and chemical (oxygen and nutrients) gradients within their walls. The availability of redox couples for microbial processes depends largely on these gradients, which therefore influence the distribution of micro-organisms within chimney walls. T. ammonificans $\mathrm{HB}-1^{\mathrm{T}}$ appears to be welladapted to inhabit the walls of active chimneys; it obtains energy from molecular hydrogen, which is generally enriched in vent fluids (Lilley et al., 1993), and it uses nitrate, which is present in the bottom sea water (Millero, 1996), as an electron acceptor. Its optimal growth conditions, with a temperature of $75^{\circ} \mathrm{C}$, a slightly acidic $\mathrm{pH}$ and a salt concentration lower than that of sea water, reflect conditions that may be found within chimney walls, where hot, reduced hydrothermal fluids mix with cold, oxygenated sea water. Whilst T. ammonificans $\mathrm{HB}-1^{\mathrm{T}}$ is a strict anaerobe, the presence of moderate catalase activity could provide protection from occasional exposure to toxic products of oxygen metabolism, which is likely to occur in a biotope that is characterized by highly fluctuating redox conditions.

Within deep-sea hydrothermal systems, ammonium has been found in appreciable quantities only in the endmember fluids of vents from the Guaymas Basin and from both the Endeavour and Explorer segments of the Juan de Fuca Ridge (Tunnicliffe et al., 1986; Lilley et al., 1993; Von Damm, 1995). In all cases, the high concentration of

Table 1. Differentiating features of $T$. ammonificans $\mathrm{HB}-1^{\top}$ and T. ruber

Taxa: 1, T. ammonificans $\mathrm{HB}-1^{\mathrm{T}}$; 2, T. ruber. Both species are negative for growth under $\mathrm{H}_{2} / \mathrm{CO}_{2}$ in the presence of formate.

\begin{tabular}{|lcc|}
\hline Feature & $\mathbf{1}$ & $\mathbf{2}$ \\
\hline Morphology & Short rods & Vibrioid \\
Optimal growth parameters: & & \\
$\mathrm{NaCl}$ concentration $(\%)$ & $2 \cdot 0$ & $3 \cdot 0$ \\
$\mathrm{pH}$ & $5 \cdot 5$ & $6 \cdot 0$ \\
Growth under $\mathrm{H}_{2} / \mathrm{CO}_{2}$ in the presence of: & & \\
Yeast extract $\left(\mathrm{g} \mathrm{l}^{-1}\right)$ & - & + \\
Acetate & - & + \\
Lactate & - & + \\
DNA G $+\mathrm{C}$ content $(\mathrm{mol} \%)$ & $54 \cdot 6$ & $46 \cdot 0$ \\
\hline
\end{tabular}


ammonium has been attributed to the decomposition of sub-sea floor organic matter that is associated with buried sediments, suggesting that ammonium is not a direct product of geothermal processes (Edmond \& Von Damm, 1985; Lilley et al., 1993). However, a recent study indicates that fluids at $65^{\circ} \mathrm{C}$, which are obtained from ageing ocean crust on the flanks of the Juan de Fuca Ridge, are highly enriched with ammonium that may be of microbial origin (Cowen et al., 2003). This observation suggests the occurrence of a sub-sea floor community of nitrateammonifying organisms. Whilst the relative abundance of nitrate-ammonifying organisms in geothermal environments is not known, they could play a critical ecological role. In principle, the ammonium produced by these organisms as a result of nitrate respiration could be used both as a nitrogen source by other vent inhabitants and as an electron donor by chemolithoautotrophic, ammoniaoxidizing bacteria. In either case, T. ammonificans-like organisms could play a pivotal role in nitrogen cycling at deep-sea hydrothermal vents.

\section{Description of Thermovibrio ammonificans sp. nov.}

Thermovibrio ammonificans (am.mo.ni'fi.cans. N.L. n. ammonium ammonium; L. v. facere to make; N.L. part. adj. ammonificans ammonifying).

Cells are short rods, about $1.0 \mu \mathrm{m}$ in length and $0.6 \mu \mathrm{m}$ in width. Motile by polar flagellation. Gram-negative. Growth occurs between 60 and $80{ }^{\circ} \mathrm{C}, 0.5$ and $4.5 \% \mathrm{NaCl}$ and $\mathrm{pH} 5$ and 7. Optimal growth conditions are $75^{\circ} \mathrm{C}, 2 \% \mathrm{NaCl}$ and $\mathrm{pH} 5.5$ (generation time, $1.57 \mathrm{~h}$ ). Strictly anaerobic. Growth occurs under chemolithoautotrophic conditions in the presence of $\mathrm{H}_{2}$ and $\mathrm{CO}_{2}$, with nitrate or sulfur as electron acceptors and concomitant formation of ammonium or hydrogen sulfide, respectively. Thiosulfate, sulfite and oxygen are not used as electron acceptors. Acetate, formate, lactate and yeast extract $\left(\mathrm{g} \mathrm{l}^{-1}\right)$ inhibit growth. No chemoorganoheterotrophic growth occurs on peptone, tryptone, yeast extract $\left(0 \cdot 1 \mathrm{~g} \mathrm{l}^{-1}\right)$, Casamino acids, glucose or sucrose. Sensitive to ampicillin and chloramphenicol, but resistant to kanamycin and streptomycin (each at $100 \mathrm{mg} \mathrm{ml}^{-1}$ ). Catalase-positive. Genomic DNA G $+\mathrm{C}$ content is $54 \cdot 6 \mathrm{~mol} \%$.

The type strain is $\mathrm{HB}-1^{\mathrm{T}}\left(=\mathrm{DSM} 15698^{\mathrm{T}}=\mathrm{JCM} 12110^{\mathrm{T}}\right)$, which was isolated from the walls of an active deep-sea hydrothermal vent chimney on the East Pacific Rise at $9^{\circ} 50^{\prime} \mathrm{N}$.

\section{Acknowledgements}

We wish to thank Cindy Van Dover for kindly providing dive time and assistance with collection of samples and Harald Huber for providing both the reference strain, T. ruber, and biomass from this strain to carry out DNA-DNA hybridization experiments. We thank Peter Schumann, Ronald Lauck, Christy Hoang and Bethany Little for excellent technical assistance. We wish to thank the crew of RV Atlantis and the crew and pilots of the deep-submergence vehicle Alvin for their skilled operations at sea. This work was supported by the New Jersey Agricultural and Experiment Station (C. V.), a Research Council grant from Rutgers University (C. V.) and NSF grants OCE 95-29819 and ESI 00-876779 (R. A. L.).

\section{References}

Alain, K., Querellou, J., Lesongeur, F., Pignet, P., Crassous, P., Raguénès, G., Cueff, V. \& Cambon-Bonavita, M.-A. (2002). Caminibacter hydrogeniphilus gen. nov., sp nov., a novel thermophilic, hydrogen-oxidizing bacterium isolated from an East Pacific Rise hydrothermal vent. Int J Syst Evol Microbiol 52, 1317-1323.

Alain, K., Rolland, S., Crassous, P. \& 9 other authors (2003). Desulfurobacterium crinifex sp. nov., a novel thermophilic, pinkishstreamer forming, chemolithoautotrophic bacterium isolated from a Juan de Fuca Ridge hydrothermal vent and amendment of the genus Desulfurobacterium. Extremophiles 7, 361-370.

Balch, W. E., Fox, G. E., Magrum, L. J., Woese, C. R. \& Wolfe, R. S. (1979). Methanogens: reevaluation of a unique biological group. Microbiol Rev 43, 260-296.

Blöchl, E., Rachel, R., Burggraf, S., Hafenbradl, D., Jannasch, H. W. \& Stetter, K. O. (1997). Pyrolobus fumarii, gen. and sp. nov., represents a novel group of archaea, extending the upper temperature limit for life to $113^{\circ} \mathrm{C}$. Extremophiles 1, 14-21.

Burggraf, S., Olsen, G. J., Stetter, K. O. \& Woese, C. R. (1992). A phylogenetic analysis of Aquifex pyrophilus. Syst Appl Microbiol 15, 352-356.

Cashion, P., Holder-Franklin, M. A., McCully, J. \& Franklin, M. (1977). A rapid method for the base ratio determination of bacterial DNA. Anal Biochem 81, 461-466.

Cord-Ruwisch, R. (1985). A quick method for the determination of dissolved and precipitated sulfides in cultures of sulfate-reducing bacteria. J Microbiol Methods 4, 33-36.

Cowen, J. P., Giovannoni, S. J., Kenig, F., Johnson, H. P., Butterfield, D., Rappe, M. S., Hutnak, M. \& Lam, P. (2003). Fluids from aging ocean crust that support microbial life. Science 299, $120-123$.

De Ley, J., Cattoir, H. \& Reynaerts, A. (1970). The quantitative measurement of DNA hybridization from renaturation rates. Eur J Biochem 12, 133-142.

Diamond, D. (1993). QuikChem Automated Ion Analyzer Methods Manual, methods no. 31-107-06-1-A and 31-107-04-1-A. Milwaukee, WI: Lachat Instruments.

Edmond, J. M. \& Von Damm, K. L. (1985). Chemistry of ridge crest hot springs. Proc Biol Soc Wash 6, 43-47.

Escara, J. F. \& Hutton, J. R. (1980). Thermal stability and renaturation of DNA in dimethyl sulfoxide solutions: acceleration of the renaturation rate. Biopolymers 19, 1315-1327.

Felsenstein, J. (1981). Evolutionary trees from DNA sequences: a maximum likelihood approach. J Mol Evol 17, 368-376.

Giovannoni, S. J. (1991). The polymerase chain reaction. In Nucleic Acid Techniques in Bacterial Systematics, pp. 177-203. Edited by E. Stackebrandt \& M. Goodfellow. New York: Wiley.

Huber, R., Rossnagel, P., Woese, C. R., Rachel, R., Langworthy, T. A. \& Stetter, K. O. (1996). Formation of ammonium from nitrate during chemolithoautotrophic growth of the extremely thermophillic bacterium Ammonifex degensii gen. nov. sp. nov. Syst Appl Microbiol 19, 40-49.

Huber, H., Diller, S., Horn, C. \& Rachel, R. (2002). Thermovibrio ruber gen. nov., sp. nov., an extremely thermophilic, chemolithoautotrophic, nitrate-reducing bacterium that forms a deep branch within the phylum Aquificae. Int J Syst Evol Microbiol 52, 1859-1865. 
Huss, V. A. R., Festl, H. \& Schleifer, K.-H. (1983). Studies on the spectrophotometric determination of DNA hybridization from renaturation rates. Syst Appl Microbiol 4, 184-192.

Jahnke, K.-D. (1992). Basic computer program for evaluation of spectroscopic DNA renaturation data from GILFORD system 2600 spectrometer on a PC/XT/AT type personal computer. J Microbiol Methods 15, 61-73.

L'Haridon, S., Cilia, V., Messner, P., Raguenes, G., Gambacorta, A., Sleytr, U. B., Prieur, D. \& Jeanthon, C. (1998). Desulfurobacterium thermolithotrophum gen. nov., sp. nov., a novel autotrophic, sulphurreducing bacterium isolated from a deep-sea hydrothermal vent. Int J Syst Bacteriol 48, 701-711.

Lilley, M. D., Butterfield, D. A., Olson, E. J., Lupton, J. E., Macko, S. A. \& McDuff, R. E. (1993). Anomalous $\mathrm{CH}_{4}$ and $\mathrm{NH}_{4}^{+}$concentrations at an unsedimented mid-ocean-ridge hydrothermal system. Nature $364,45-47$.

Mesbah, M., Premachandran, U. \& Whitman, W. B. (1989). Precise measurement of the $\mathrm{G}+\mathrm{C}$ content of deoxyribonucleic acid by highperformance liquid chromatography. Int J Syst Bacteriol 39, 159-167.

Millero, F. J. (1996). Micronutrients in the oceans. In Chemical Oceanography, 2nd edn, pp. 281-305. Edited by M. J. Kennish \& P. L. Lutz. Boca Raton, FL: CRC Press.

Miroshnichenko, M. L., Kostrikina, N. A., Chernyh, N. A., Pimenov, N. V., Tourova, T. P., Antipov, A. N., Spring, S., Stackebrandt, E. \& Bonch-Osmolovskaya, E. A. (2003). Caldithrix abyssi gen. nov., sp. nov., a nitrate-reducing, thermophilic, anaerobic bacterium isolated from a Mid-Atlantic Ridge hydrothermal vent, represents a novel bacterial lineage. Int J Syst Evol Microbiol 53, 323-329.

Reysenbach, A.-L., Wickham, G. S. \& Pace, N. R. (1994). Phylogenetic analysis of the hyperthermophilic pink filament community in Octopus Spring, Yellowstone National Park. Appl Environ Microbiol 60, 2113-2119.

Stetter, K. O., König, H. \& Stackebrandt, E. (1983). Pyrodictium gen. nov., a new genus of submarine disc-shaped sulfur reducing archaebacteria growing optimally at $105^{\circ}$ C. Syst Appl Microbiol 4, $535-551$.

Tivey, M. K. (1995). The influence of hydrothermal fluid composition and advection rates on black smoker chimney mineralogy: insights from modeling transport and reaction. Geochim Cosmochim Acta 59, 1933-1949.

Tunnicliffe, V., Botros, M., de Burgh, M. E., Dinet, A., Johnson, H. P., Juniper, S. K. \& McDuff, R. E. (1986). Hydrothermal vents of Explorer Ridge, northeast Pacific. Deep-Sea Res 33, 401-412.

Vetriani, C., Jannasch, H. W., MacGregor, B. J., Stahl, D. A. \& Reysenbach, A.-L. (1999). Population structure and phylogenetic characterization of marine benthic archaea in deep-sea sediments. Appl Environ Microbiol 65, 4375-4384.

Von Damm, K. L. (1995). Controls on the chemistry and temporal variability of seafloor hydrothermal fluids. In Seafloor Hydrothermal Systems: Physical, Chemical, Biological, and Geological Interactions (Geophysical monograph 91), pp. 222-247. Edited by S. E. Humphris, R. A. Zierenberg, L. S. Mullineaux \& R. E. Thomson. Washington, DC: American Geophysical Union.

Wayne, L. G., Brenner, D. J., Colwell, R. R. \& 9 other authors (1987). International Committee on Systematic Bacteriology. Report of the ad hoc committee on reconciliation of approaches to bacterial systematics. Int J Syst Bacteriol 37, 463-464.

Weisburg, W. G., Barns, S. M., Pelletier, D. A. \& Lane, D. J. (1991). $16 \mathrm{~S}$ ribosomal DNA amplification for phylogenetic study. J Bacteriol 173, 697-703. 